\title{
Effects of butaphosphan and cyanocobalamin mixture on immunity and stress in olive flounder, Paralichthys olivaceus
}

Seung Min Kim¹, You Jeong Kim², Da Won Lee ${ }^{3}$, Lyu Jin Junn', Joon Bum Jeong ${ }^{4}$, Hyun Kyung Park You Young Jeong ${ }^{2}$, Sung Ho Lee ${ }^{2}$, Mun-Gyeong Kwon ${ }^{3}$ and Soon Jeong Lee (D) $^{*}$

\begin{abstract}
Background: The study evaluated the effects of a butaphosphan and cyanocobalamin mixture on the immune system and stress in olive flounders, Paralichthys olivaceus.

Methods: The mixture was intramuscularly injected into olive flounders at the current recommended dose. Furthermore, to determine the toxicity of overdose, a histological examination was performed after injection of 1-, 2-, and 4-fold higher than the recommended dose.

Results: Immunity parameters were altered during the first 2 weeks after a single intramuscular injection of the mixture in olive flounders (average weight $20.5 \pm 1.1 \mathrm{~g}$ ). The levels of all tested items, except glutathione and antiprotease, were higher in the treated group than in the control group in the first week; the levels of all tested items were even higher in the second week in the treated group than in the control group. The level of nitro-blue tetrazolium, myeloperoxidase, and superoxide dismutase between the two groups differed significantly. Changes in the stress response to different seawater temperatures (increase or decrease in seawater temperature by $3-5^{\circ} \mathrm{C}$ using $50 \mathrm{~L}$ heated or cooled seawater tanks) were studied by determining the changes in cortisol and glucose levels on days 1 and 7. Both cortisol and glucose levels were significantly lower in the treated group than in the control group. Histological analysis did not reveal any abnormalities after intramuscular injection of the mixture at doses that were 1-, 2-, and 4-fold higher than the recommended dose.
\end{abstract}

Conclusions: Intramuscular injection of a butaphosphan and cyanocobalamin mixture is safe and effective in reducing stress and improving immunity in olive flounders.

Keywords: Butaphosphan, Cyanocobalamin, Immunity, Olive flounder, Stress

\section{Background}

Olive flounder is a popular seafood and a commercially important fish in Korea; it accounted for about $46.2 \%$ of the total cultured fish domestic production of 37,238 tons in 2018 (KOSIS 2018). However, increased infection

\footnotetext{
* Correspondence: leesj73@korea.kr

'Seaweed Research Center, National Institute of Fisheries Science, Mokpo 58746, South Korea

Full list of author information is available at the end of the article
}

rate, stunted growth, and decline in the capability to maintain homeostasis and necessary immunity are reasons why the commercial production of this fish has resulted in economic losses. These problems are associated with poor water quality and stress caused by highdensity culture to meet the excessive demand for this fish (Maule et al. 1989; Kang et al. 2007).

Most domestic fish farms of olive flounder are set up by using running water at the natural water temperature

(c) The Author(s). 2020 Open Access This article is licensed under a Creative Commons Attribution 4.0 International License, which permits use, sharing, adaptation, distribution and reproduction in any medium or format, as long as you give appropriate credit to the original author(s) and the source, provide a link to the Creative Commons licence, and indicate if changes were made. The images or other third party material in this article are included in the article's Creative Commons licence, unless indicated otherwise in a credit line to the material. If material is not included in the article's Creative Commons licence and your intended use is not permitted by statutory regulation or exceeds the permitted use, you will need to obtain permission directly from the copyright holder. To view a copy of this licence, visit http://creativecommons.org/licenses/by/4.0/. 
(Kim et al. 2015). However, large water temperature fluctuations during summer and winter are unsuitable for the optimum growth of olive flounder; consequently, this puts the fish under stress (Barton and Iwama 1991). Stress increases the level of cortisol and glucose in fish (Davis and Parker 1990; Demers and Bayne 1997) and weakens the immune system by reducing the activities of complement, lysozyme, etc. (Sunyer and Tort 1995). The butaphosphan and cyanocobalamin aquaculture drug mixture (BPC) is being used in domestic fish farms to reduce stress and improve growth and immunity and, thus, to reduce the negative effects of the environment. $\mathrm{BPC}$ has been used widely in the livestock industry (e.g., for the production of cattle and pigs) and reported to improve liver function, tissue regeneration, and absorption of nutrients by increasing hematogenesis (Flasshoff 1974) and reduce stress by lowering the cortisol concentration (Deniz et al. 2009). Reduced cortisol levels in fish help to maintain normal immune parameters (Seo et al. 2020), and even under high-density culture stress, a reduction in the levels of IL-B, AST, and ALT helps to prevent loss of immunity function and tissue damage (Mechesso et al. 2019). However, research on the effects of $\mathrm{BPC}$ in fish is scant.

$\mathrm{BPC}$ is regarded as safe and is free of any residual and toxic components (MFDS 2013; EPMAR 2014). However, there have been reports drawing a correlation between BPC administration and tissue damage and mortality in fish. It is possible that the dose used at some fish-farming sites is higher than that recommended. However, to get more clarity, we conducted this study to obtain relevant safety and efficacy data of BPC administration in the cultured olive flounder.

\section{Methods}

\section{Fish}

Olive flounders (Paralichthys olivaceus) with no history of disease or infection were purchased from a local fish farm in Jeju Island. Fish were moved to the Marine Environment Research Institute of Jeju National University and were acclimatized for 1 week to the experimental environment (Fig. 1).

The photoperiod was maintained at $12 \mathrm{~h}$ using fluorescent lamps. The temperature of seawater used for culturing was maintained at $20-23{ }^{\circ} \mathrm{C}$. Fish were fed standard food (approximately $3 \%$ of the body weight) twice daily at 9 am and $6 \mathrm{pm}$.

\section{Sample collection}

Five fish were selected at random from the control and BPC groups. The fish were anesthetized using 2phenoxyethanol solution (100 ppm). Blood samples were taken from the tail vein using a heparin-treated syringe and separated by centrifugation (5000 rpm for $10 \mathrm{~min}$ ).
Immunity and stress markers were quantified in the blood and serum. Each analysis was performed in triplicate.

\section{Test material}

BPC mixture, approved by the National Institute of Fisheries Science's as an abdominal and intramuscular injection aquaculture drug (butaphosphan $100 \mathrm{mg}$ and cyanocobalamin $0.05 \mathrm{mg} / \mathrm{mL}$ ), was used at the recommended dose $(0.5 \mathrm{~mL} / \mathrm{kg}$ of fish body weight).

\section{Biochemical measurements and safety assessment (recommended BPC dose)}

Olive flounders $(n=180$; average weight $20.5 \pm 1.1 \mathrm{~g}$ ) were placed into six (30 fish each/three petitions per group) $120-\mathrm{L}$ water tanks containing seawater and grouped as follows: control group intramuscularly administered $0.01 \mathrm{~mL}$ of phosphate-buffered saline and test groups intramuscularly administered BPC.

The feeding, behavior, branchial movement, internal and external features, and mortality were evaluated daily until day 14 after BPC administration. Immunity status was evaluated on day 7 and 14 after BPC administration and was based on the levels of lysozyme (LZM), nitroblue tetrazolium (NBT), superoxide dismutase (SOD), myeloperoxidase (MPO), glutathione peroxidase (GPx), anti-protease (AP), and the total immunoglobulin (TIg) analyses.

\section{LZM analysis}

Serum LZM activity was determined by a turbidometric assay (Yeh et al. 2008) utilizing lyophilized Micrococcus lysodeikticus cells (Sigma, USA). Briefly, each well of an ELISA plate was filled with $10 \mu \mathrm{L}$ of serum from individual fish, mixed with $200 \mu \mathrm{L}$ of an M. lysodeikticus suspension $(0.2 \mathrm{mg} / \mathrm{mL}$ in $0.05 \mathrm{M}$ sodium phosphate buffer [pH 6.2]), maintained at $25^{\circ} \mathrm{C}$, and the absorbance measured at $530 \mathrm{~nm}$ after 1 and 6 min using a plate reader. Each unit of LZM activity corresponded to a $0.001 / \mathrm{min}$ decrease in sample absorbance.

\section{NBT analysis}

The activation of serum macrophages was determined by measuring the neutrophil oxidative-radical generation using the method of Kumari and Sahoo (2005). Samples of whole blood $(50 \mu \mathrm{L})$ and NBT solution $(0.2 \%)$ were placed in a glass test tube, to which $1 \mathrm{~mL}$ of dimethyl formamide was added to reduce the generated formazan. After centrifugation at 2000I $g$ for $5 \mathrm{~min}$, the extent of NBT reduction was determined by measuring the absorbance of the supernatant at $540 \mathrm{~nm}$ (Genesys 10UA, USA). Dimethyl formamide was used as the blank. 


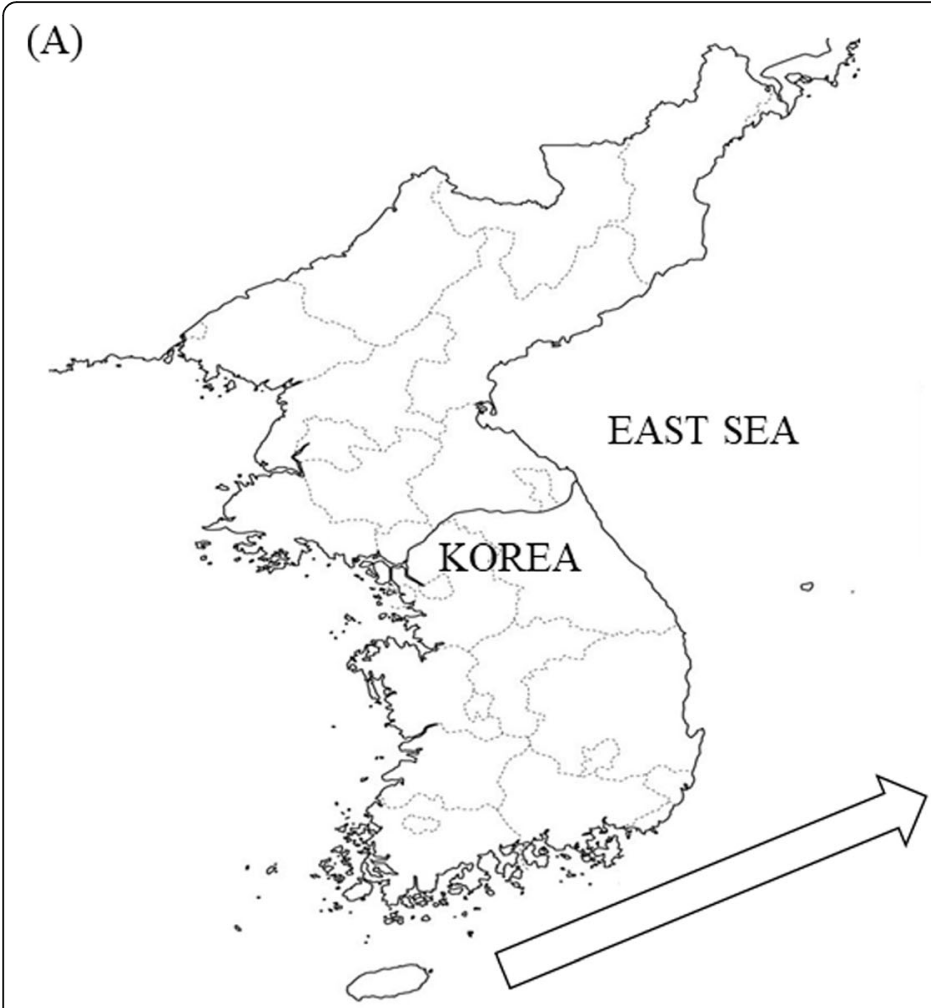

(B)

Jeju Island

Fig. 1 Map showing the location of the study area. a Location of Jeju Island and $\mathbf{b}$ map of Jeju Island showing topography and location of Hamdeok

\section{SOD analysis}

Serum SOD activity was quantified using the SOD assay kit (Sigma, 19160). Samples $(20 \mu \mathrm{L})$ and $20 \mu \mathrm{L}$ of WST working solution were placed in a 96-well microplate, $15 \mu \mathrm{L}$ of the enzyme solution was added, the mixture was diluted with $2.5 \mathrm{~mL}$ of the dilution buffer, and the content was mixed. After incubation for $20 \mathrm{~min}$ at $37^{\circ} \mathrm{C}$, the absorbance was measured at $450 \mathrm{~nm}$ with a microplate reader (Thermo, USA). The results were calculated using the formula

$$
\begin{gathered}
\text { [Ablank } 1 \text { - Ablank 3] - } \text { (Sample - Blank 2)/Ablank } 1 \\
- \text { Ablank 3] } \times 100
\end{gathered}
$$

\section{MPO analysis}

Serum MPO activity was determined using the method of Kumari and Sahoo (2005). Each well of a 96-well plate was filled with $80 \mu \mathrm{L}$ of Hanks balanced salt solution and $20 \mu \mathrm{L}$ of serum, $20 \mathrm{mM}$ of 3,3',5,5'-tetramethybenzidine, and $5 \mathrm{mM} \mathrm{H}_{2} \mathrm{O}_{2}$ were added. After a reaction time of $2 \mathrm{~min}$, then $15 \mu \mathrm{L}$ of $4 \mathrm{M} \mathrm{H}_{2} \mathrm{SO}_{4}$ solution was added before the absorbance was measured at $450 \mathrm{~nm}$ using a microplate reader (Thermo, USA).

\section{GPx analysis}

Serum GPx activity was measured following the instructions of the GPx activity kit (Biovision, Inc., Milpitase, CA, USA). Serum samples were placed into a 96-well plate; solutions of NADH, glutathione, and glutathione reductase were added; and absorbance was measured at $340 \mathrm{~nm}$ using a microplate reader.

\section{AP analysis}

Serum AP activity was determined using the method of Ellis (1990). Serum samples $(20 \mu \mathrm{L})$ were mixed with $20 \mu \mathrm{L}$ of trypsin solution and reacted at $22^{\circ} \mathrm{C}$ for $10 \mathrm{~min}$. Then, $200 \mu \mathrm{L}$ of phosphate buffer $(0.1 \mathrm{M}, \mathrm{pH} 7.0)$ and $250 \mu \mathrm{L}$ of azocasein $(2 \%)$ were added to each sample, and the mixtures were reacted at $22^{\circ} \mathrm{C}$ for $30 \mathrm{~min}$. The samples were centrifuged at $6000 \mathrm{I} g$, and $100 \mu \mathrm{L}$ aliquots of supernatants were placed in the wells of a 96-well plate together with $100 \mu \mathrm{L}$ of $\mathrm{NaOH}(1 \mathrm{~N})$. The absorbance was determined at $430 \mathrm{~nm}$.

\section{Tlg analysis}

TIg was determined in the serum using the method of Siwicki and Anderson (1993). Immunoglobulins were precipitated with $12 \%$ polyethylene glycol (Sigma, USA) 
and quantified using the standard Bradford assay kit (Sigma C-690).

\section{Statistical analysis}

SPSS (Ver. 21) statistical analysis program was used to perform the $T$ test. Statistical significance was set at $P<$ 0.05 .

\section{Analysis of stress caused by changes in seawater temperature}

Olive flounders $(n=120$; average weight $20.5 \pm 1.1 \mathrm{~g})$ were placed in six (20 fish each/three petitions per group) 50-L water tanks that could be heated or cooled and grouped as follows: control group intramuscularly injected with $0.01 \mathrm{~mL}$ of phosphate-buffered saline and test groups intramuscularly injected with BPC. Water temperature was cooled and heated (by $3-5^{\circ} \mathrm{C}$ ) alternately every $24 \mathrm{~h}$ by using cooling $\left(17-19^{\circ} \mathrm{C}\right)$ thermostats and heating $\left(20-22^{\circ} \mathrm{C}\right)$ rods, respectively. Cortisol and glucose levels were determined on day 1 and day 7 . The study was conducted for 7 days only since the possibility of olive flounders dying because of the changes in water temperature needed to be considered; hence, the fish mortality rate was also observed.

\section{Cortisol analysis}

The serum cortisol level was measured by an enzyme immunoassay kit (Bio vision, USA).

\section{Glucose analysis}

Serum glucose was determined using an automatic biochemical analyzer (IDDXX, USA).

\section{Statistical analysis}

Statistical analysis was conducted in the same way as for the immunological method using SPSS (Ver. 21) statistical analysis program to perform the $T$ test and to determine the data statistical significance at $P<0.05$.

\section{Safety assessment (BPC overdose)}

Olive flounders $(n=240$; average weight $20.5 \pm 1.1 \mathrm{~g})$ were placed in 12 (20 fish each/three petitions per group) 100-L water tanks containing seawater and grouped as follows: control group intramuscularly injected with $0.01 \mathrm{~mL}$ of phosphate-buffered saline and test groups intramuscularly injected with $0.01 \mathrm{~mL}, 0.02$ $\mathrm{mL}$, and $0.04 \mathrm{~mL}$ of BPC. Histological analysis was conducted to evaluate the effect of an overdose of BPC on day 7 and day 14 after administration using five randomly collected fish from each group.

\section{Histological analysis}

The liver, kidneys, spleen, gill, intestines, and muscles (injected area) were extracted from fish, fixed in Bouin's solution for $24 \mathrm{~h}$, and dehydrated using $70 \% \mathrm{EtOH}$. Tissues were embedded in paraffin (Leica EG 1150HC, Germany) using an embedder (Leica Jung 820, Germany), sliced using a microtome, attached to glass slides, dried, and stained with hematoxylin and eosin. Microscopic examination of these tissues was carried out using an optical microscope (Zeiss LT60, Germany) to observe any abnormal histological changes that may have been caused by BPC.

\section{Results}

Biochemical measurements and safety assessment (recommended BPC dose)

The safety of BPC was tested in comparison with a control group. No increased mortality or abnormal findings in food intake, internal/external features, and branchial movement were seen (data not shown). LZM, NBT, SOD, MPO, and TIg values, except for GPx and AP activity, were higher in the BPC group than in the control group in the first week, but no significant differences were observed except for the LZM activity (Table 1). The values of all these immunity markers were higher in the second week than in the first week, with higher values being observed in the BPC group than in the control group for all markers. Significant differences were observed in NBT, MPO, and SOD activities between the two groups (Table 1 ).

\section{Reduction of stress caused by changes in seawater temperature}

Significantly lower levels of cortisol and glucose were found in the BPC group than in the control group (Fig. 2). Fish deaths associated with changes in seawater temperature occurred from day 5 in the control group and reached $20 \%$ mortality on the last day of the test, whereas no mortality was observed during the same period in the BPC group (Fig. 3).

\section{Safety assessment (BPC overdose)}

During the 14 days of the study, no abnormality or mortality was observed in any of the groups (data not shown). Histological analysis showed similar results for all the BPC groups. The gill plates and gill filaments showed a constant configuration, and no signs of toxicity, such as bleeding, congestion on gills, or necrosis of epithelial cells, were observed in any of the test groups. No fish showed abnormalities in the muscle injected with BPC, and while minor degeneration was seen in the muscle fiber, similar minor degeneration was observed even in the control group. No bleeding or infiltration of inflammatory cells was observed. No toxic effects such as misalignment of liver cells due to damage to the hepatic cord or degeneration of the tubular epithelial cells in the kidneys caused by the administration of BPC were 
Table 1 The effect of BPC on immune responses for 1 week and 2 weeks. BPC was injected intramuscularly at a dose of $0.01 \mathrm{~mL}$

\begin{tabular}{lllllllll}
\hline & Groups & $\begin{array}{l}\text { LZM } \\
\text { (units/mL) }\end{array}$ & $\begin{array}{l}\text { NBT } \\
\text { (absorbance) }\end{array}$ & $\begin{array}{l}\text { SOD } \\
\text { (\%, inhibition) }\end{array}$ & $\begin{array}{l}\text { MPO } \\
\text { (absorbance) }\end{array}$ & $\begin{array}{l}\text { GPx } \\
\text { (mU/mL) }\end{array}$ & $\begin{array}{l}\text { AP } \\
\text { (\%, inhibition) }\end{array}$ & $\begin{array}{l}\text { Tlg } \\
\text { (mg/mL) }\end{array}$ \\
\hline 1 week & Control & $16 \pm 1$ & $0.87 \pm 0.01$ & $49 \pm 7.46$ & $1.64 \pm 0.28$ & $15.1 \pm 2.02$ & $60.3 \pm 3.51$ & $21.2 \pm 2.26$ \\
& BPC & $18.3 \pm 4.04^{*}$ & $0.88 \pm 0.005$ & $53 \pm 0.73$ & $1.73 \pm 0.32$ & $13.3 \pm 3.27$ & $59.3 \pm 1.53$ & $21.3 \pm 0.66$ \\
2 weeks & Control & $22.3 \pm 3.78$ & $0.93 \pm 0.002$ & $51.2 \pm 3.52$ & $1.81 \pm 0.11$ & $28.2 \pm 2.89$ & $75 \pm 3.61$ & $25.6 \pm 2.64$ \\
& BPC & $25 \pm 4.58$ & $0.95 \pm 0.007^{*}$ & $56.1 \pm 5.32^{*}$ & $2.01 \pm 0.09^{*}$ & $30.1 \pm 3.08$ & $77 \pm 2$ & $27.6 \pm 1.93$ \\
\hline
\end{tabular}

Values are mean $\pm \mathrm{SE}(n=3)$

LZM lysozyme, NBT nitro-blue tetrazolium, SOD superoxide dismutase, MPO myeloperoxidase, GPx glutathione peroxidase, AP anti-protease, Tig total immunoglobulin

*Significant difference between the control group and the BPC group based on the $t$ test $(P<0.05)$

observed. Red blood cells were observed in the spleen tissue of olive flounders in both the treated and control groups, but no increase in white blood cells was observed. BPC injection did not cause any inflammation or other toxic effects. There were no changes over time to the normal histology after BPC administration (Fig. 4).

\section{Discussion}

$\mathrm{BPC}$ is used in domestic fish farms of olive flounder as a registered aquaculture drug to improve immunity and reduce stress in fish (Mechesso et al. 2019; National Institute of Fisheries Sciences 2018; Seo et al. 2020). Although BPC is shown to be effective based on its application in the livestock industry (Pereira et al. 2013a, 2013b; Tabeleao et al. 2017), its effects on fish remain unclear. In this study, BPC was intramuscularly injected into olive flounders at the current recommended dose, and tests were conducted to determine the effects of $\mathrm{BPC}$ on immunity and stress. Furthermore, the toxic effects of BPC overdose (1-, 2-, and 4-fold higher than the recommended dose) were studied based on histological examination.
An increase in non-specific immune response reduces mortality and improves fish health (Ji et al. 2007; Yuan et al. 2007; Citarasu 2010). LZM is a widely distributed enzyme that plays a major role in the defense mechanism of higher animals as it functions as an opsonin and protects against microbes (e.g., viruses and bacteria) and disease conditions (e.g., cancer) (Jollès and Jollès 1984). NBT increases reactive oxygen species (ROS) formation by hydrolyzing invading organisms such as viruses and bacteria. MPO plays a role in the inflammatory response; it induces toxicity in the deceased host when destroying the invading organisms (Palić et al. 2005). Activation of SOD and GPx antioxidant enzymes is known to prevent ROS-mediated cell damage (Lopes et al. 2001). TIg improves immunity as it increases acidophilic granulocytes (Picchietti et al. 2007). Our study showed higher immunity in fish treated with BPC than in control fish; this was inferred as all measured parameters improved in the BPC groups whereas only one the control group that improved in the second week. Hasi et al. 2005a, 2005b reported that butaphosphan improved humoral and cellmediated immune responses in mice; we observed the
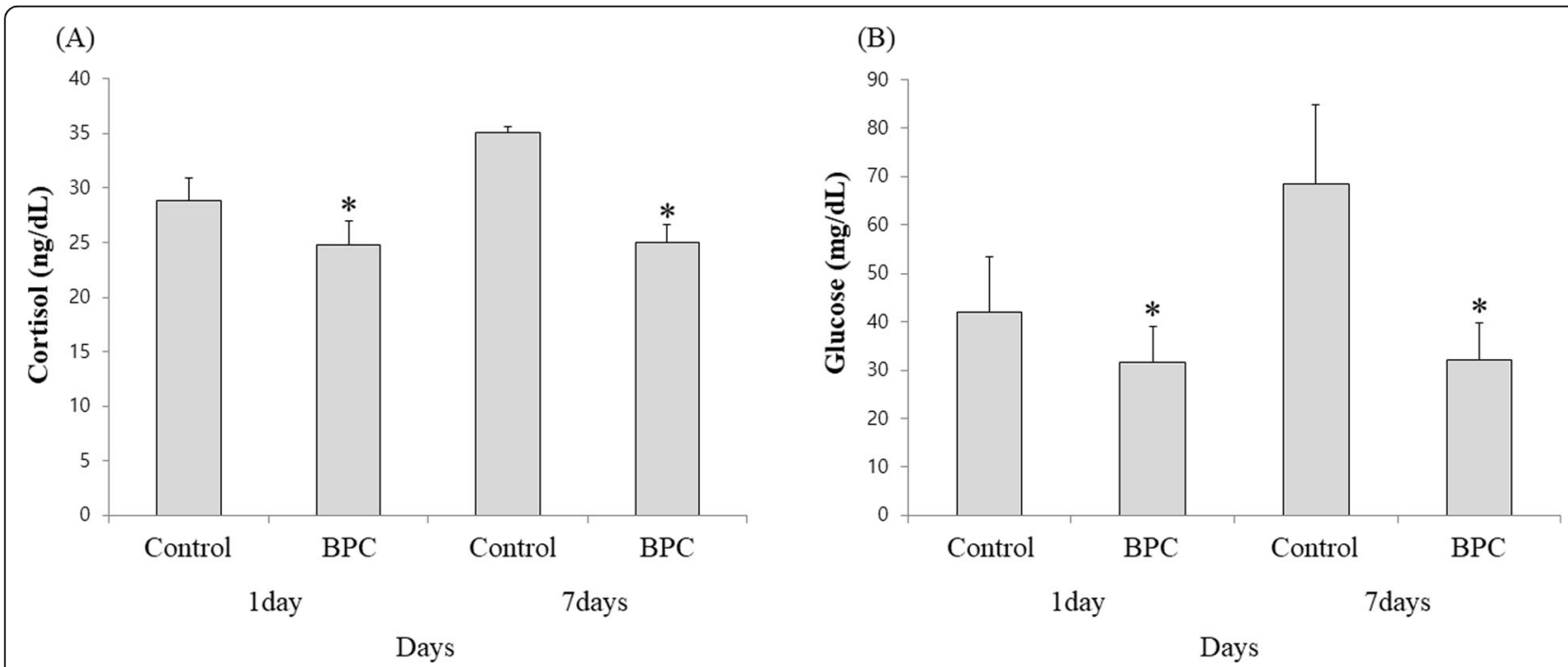

Fig. 2 Effect of BPC on stressed responses. BPC was injected intramuscularly at a dose of $0.01 \mathrm{~mL}$. a Cortisol and $\mathbf{b}$ glucose 


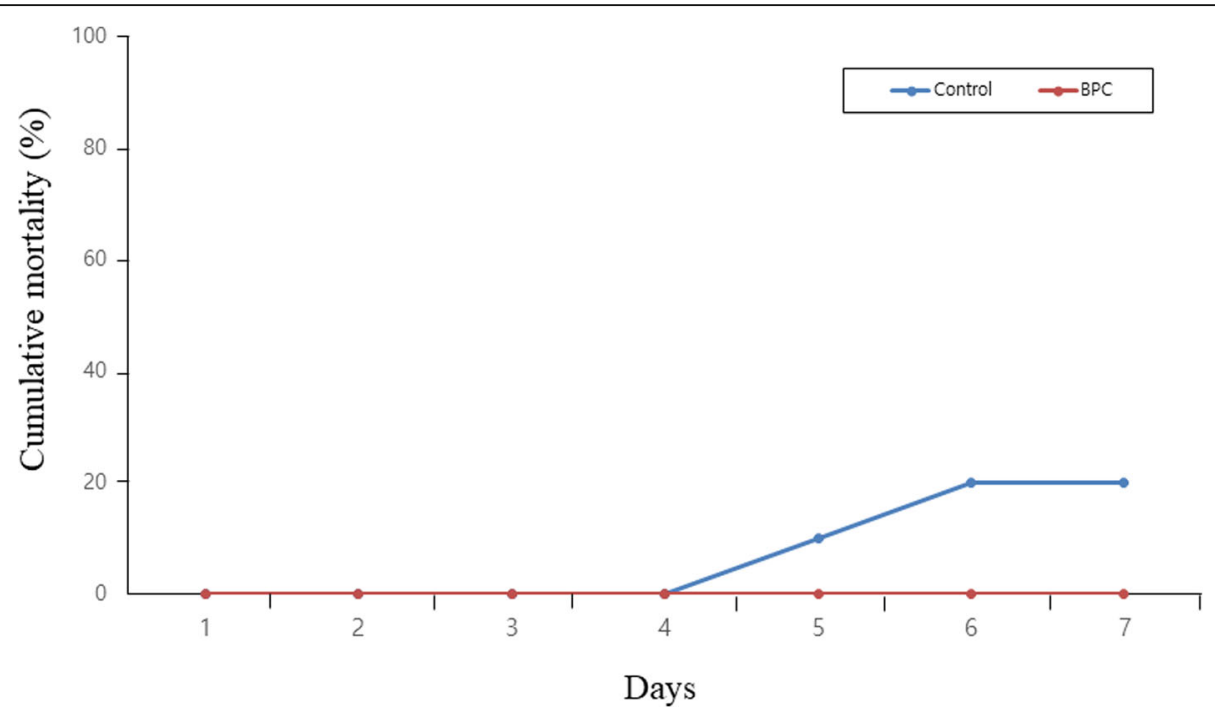

Fig. 3 Cumulative mortality in the control group and the BPC group in 1 week

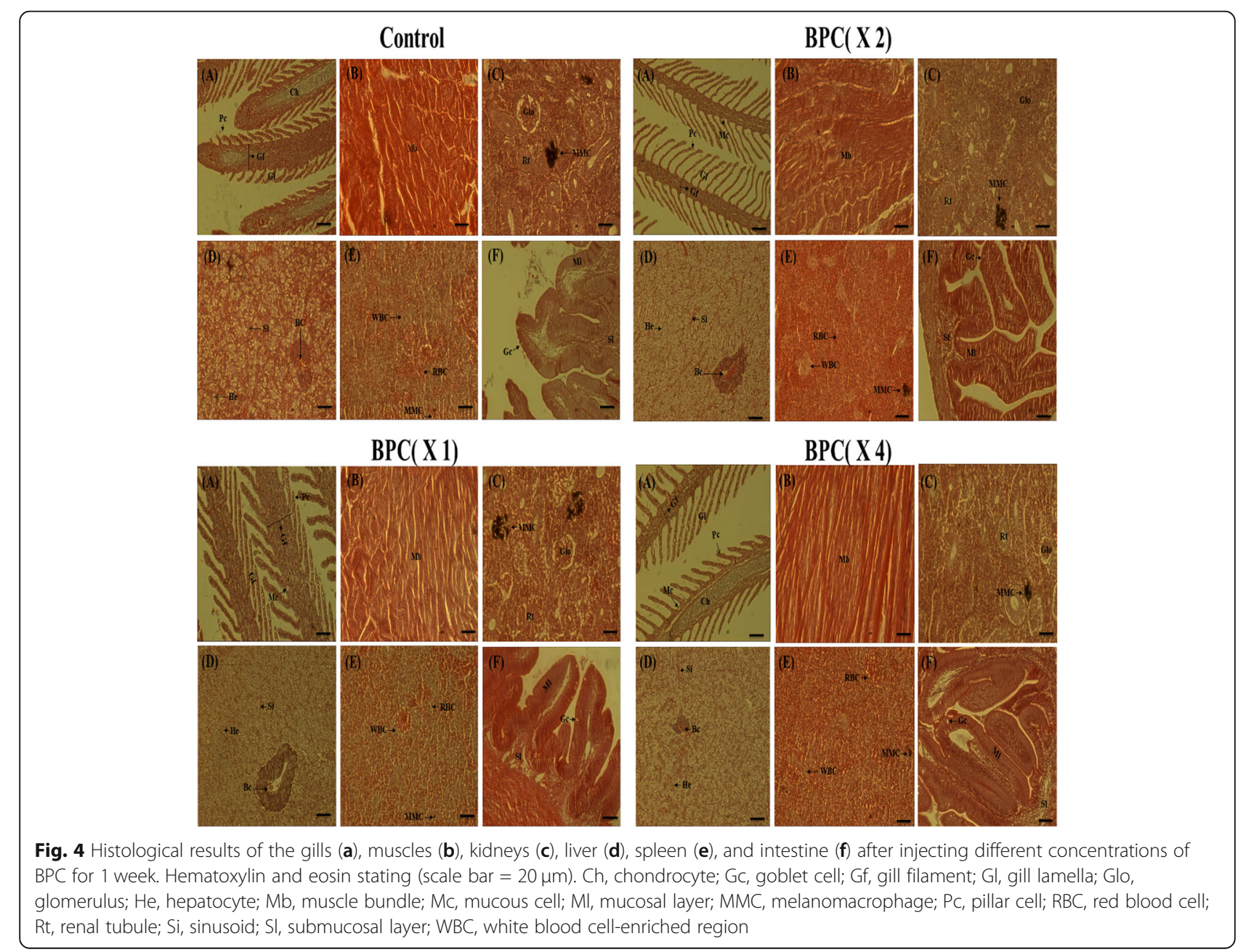


same in the present study in fish. We observed that fish treated with BPC showed excellent feeding behaviors than control fish when similar feed amounts were supplied. This result may also have some effect on immunity. However, we could not assess the possible action mechanisms of BPC that would promote appetite and immunity; additional tests will be needed to identify such mechanisms.

Factors that could activate stress in fish farms might include physical (selection or transport), chemical (changes in seawater temperature, salinity, or dissolved oxygen), and mental and social stress (high-density culture or sound) (Donaldson 1981). Unlike fish grown in their natural environment, cultured fish may always be exposed to stress as they are cultured in a closed and limited space (Pickering 1990).

Fish cultured under stress for a long time may have increased disease incidence owing to their decreased ability to maintain homeostasis, lesser resistance to stress, and lower immunity, all of which contribute to increased mortality (Heo et al. 2002; Yang et al. 2016).

This study adopted the anesthetic approach suggested by Wer et al. (2009), which involved limiting the time under anesthesia to $3 \mathrm{~min}$ and the recovery time to 5 min to suppress a possible long-term physiological stress due to the applied anesthetic.

We observed significantly lower levels of cortisol and glucose in the BPC groups than in the control group. Seo et al. (2020) tested stress in BPC-treated olive flounders kept under high-density culture conditions and reported that cortisol levels decreased sharply in the BPC group compared to those in the control group (phosphate-buffered saline-treated fish); the results of our study are similar. BPC is an amino acid phosphonic acid derivative; while its exact mechanism of action has not been elucidated (EMEA 1999), it was reported that it can accelerate the production of ATP by supplying inorganic phosphate to support oxidative phosphorylation that is an important metabolic process in ATP generation (Hasi et al. 2005a, 2005b). Seo et al. (2020) reported that ATP concentration in olive flounders that received an intramuscular injection of BPC increased compared with that in the control group (phosphatebuffered saline-treated fish). It is likely that the increase in ATP production contributed to the stress reduction by compensating for the stress-induced energy loss; elucidation of the exact underlying mechanisms here would be of interest.

Hematological factors are used as indicators of physiological stress in fish in response to changes in water temperature (Adam 1990; Cataldi et al. 1998). Glucose is one of the factors that, via a secondary reaction, increases cortisol level; increased blood glucose acts as an energy source and compensates for the changes in energy metabolism dynamics that occur when fish are under stress (Barton and Iwama 1991). We determined whether the reduced glucose concentration in the BPC group was related to the energy consumed under stress. Although our results match those by Chang et al. (2001) and show a close correlation with the decreased cortisol levels, further studies might be beneficial to elucidate the mechanism connecting stress, glucose, cortisol, and BPC.

The permitted residual quantities of veterinary drugs used in domestic animals are determined by combining toxicological evaluation and permitted residual quantity evaluation considering international standards. However, butaphosphan and vitamins are classified as safe and are exempt from the evaluation of the residual quantity and toxicity limits (MFDS 2013; EPMAR 2014).

Aquaculture drugs used in fish farms are excreted by or disappear naturally in fish if the dose and usage comply with the existing standards. This can ensure the safety of sea foods. However, some fish farms tend to administer drugs in excessive amounts over the recommended dose. We conducted histological analysis after BPC was administered at 1-, 2-, and 4-fold higher than the recommended dose to determine its safety. The results showed that BPC did not alter the histological findings and that it was safe for olive flounders even at a dose 4-times higher $(0.04 \mathrm{~mL})$ than the recommended dose. No side effects were observed with the high dose of BPC.

Seo et al. (2020) reported that the AST level significantly increased within $24 \mathrm{~h}$ after injecting $0.3 \mathrm{~mL} / \mathrm{kg}$ BPC into olive flounders without any toxicity. Histological examination in this study showed normal liver tissues, which is a natural consequence of a long-term investigation as the drug is excreted from the body or disappears naturally over time with no complications seen histologically.

The results of our study indicate that intramuscular injection of BPC improves the immunity of, and reduces stress in, olive flounders. The relationships between immunity and appetite and between immunity and stress are still to be elucidated. In addition, field test data on $\mathrm{BPC}$ use will be required.

\section{Conclusion}

BPC effectively and safely reduces stress levels by reducing the production of cortisol and glucose. BPC improves the health of olive flounder, especially when administered before or during stressful situations.

\section{Abbreviations}

BPC: Butaphosphan and cyanocobalamin mixture; LZM: Lysozyme; GPx: Glutathione peroxidase; AP: Anti-protease; NBT: Nitro-blue tetrazolium; MPO: Myeloperoxidase; ROS: Reactive oxygen species; SOD: Superoxide dismutase; Tlg: Total immunoglobulin 


\section{Acknowledgements}

This work was supported by a grant from the National Institute of Fisheries Science (R2020060).

\section{Authors' contributions}

SMK conducted the research, analyzed the samples, and drafted the manuscript. YJK, DWL, LJJ, JBJ, and HKP helped in the research experiments and statistical analysis. YYJ, SHL, and MGK reviewed the manuscript. SJL designed the experiment and finalized the manuscript. All authors read and approved the final manuscript.

\section{Funding}

This work was supported by a grant from the National Institute of Fisheries Science, Republic of Korea (R2020060).

\section{Availability of data and materials}

All datasets generated and/or analyzed during the current study are available from the corresponding author on a reasonable request.

\section{Ethics approval and consent to participate}

Not applicable.

\section{Consent for publication}

Not applicable.

\section{Competing interests}

The authors declare that they have no competing interests.

\section{Author details}

${ }^{1}$ Seaweed Research Center, National Institute of Fisheries Science, Mokpo 58746, South Korea. ${ }^{2}$ Central Research Institute, Woogene B\&G, Gyeonggi 18629, South Korea. ${ }^{3}$ Aquatic Life Disease Control Division, National Institute of Fisheries Science, Busan 46083, South Korea. ${ }^{4}$ Department of Aquatic Biomedical Science, Jeju National University, Jeju 63243, South Korea.

Received: 27 May 2020 Accepted: 31 August 2020

Published online: 24 September 2020

\section{References}

Adam SM. Biological indicators of stress in fish. Am Fish. 1990:1-8.

Barton BA, Iwama GK. Physiological changes in fish from stress in aquaculture with emphasis on the response and effects of corticosteroids. Annu Rev Fish Dis. 1991;1:3-26. https://doi.org/10.1016/0959-8030(91)90019-G.

Cataldi E, Marco PDI, Mandich A, Cataudella S. Serum parameters of Adriatic sturgeon Acipenser naccarii(Pisces: Acipenseriformes): effects of temperature and stress. Comp Biochem Physiol. 1998;121:351-4. https://doi.org/10.1016/ s1095-6433(98)-10134-4.

Chang YJ, Hur JW, Moon SH, Lee JU. Stress response of olive flouder Paralichthys olivaceus and Japanese croaker Nibea Jponica to live transportation. J Kor Fish. 2001;14:57-64.

Citarasu T. Herbal biomedicines: a new opportunity for aquaculture industy. Aquac Int. 2010:18:403-14. https://doi.org/10.1007/s10499-099-9253-7.

Davis KB, Parker NC. Physiological stress in striped bass: effect of acclimation temperature. Aquaculture. 1990;91:349-58. https://doi.org/10.1016/00448486(90)90199-W.

Demers NE, Bayne CJ. The immediate effects of stress on hormones and plasma lysozyme in rainbow trout. Dev Comp Immunol. 1997;21:363-73. https://doi. org/10.1016/50145-305X(97)00009-8.

Deniz A, Spiecker-Hauser U, Rhagen M. Efficacy of a butafosfan and vitamin B12 combination on biochemical and hematological blood parameters in in dogs treated with dexamethason. Int J Appl Res Vet Med. 2009;7:116-29.

Donaldson EM. The pituitary-interrenal axis as anindicator of stress in fish. In: Pickering AD, editor. Stress in Fish. London: Academic Press; 1981. p. 11.

Ellis AE. Serum anti-protease in fish. In: Stolen JS, Fletcher TC, Anderson DP, Roberson WB, Van Muiswinkel WB, editors. Techniques in fish immunology: SOS Publication; 1990. p. 95-9.

EMEA. The European Agency for the Evaluation of Medicinal products. Veterinary Medicines and Information Technology Unit. EMEA/MRL/630/99-FINAL. London: EMEA; 1999. p. 1-3.

EPMAR. European Public MRL Assement Report Butafosfan (all mammalian food producing species), 2014. EMA/CVMP/335153/2013.
Flasshoff FH. Clinical and chemical blood serum investigations in cattle and treatment studies with ornithine-aspartate product HMV20 and with catosal for the reduction of fertility and health disorders. Germany: Tierarztliche Hochschule Hannover; 1974.

Hasi S, Du X, Jiang J, Zhu B. Study on immune stimulating properties of compound butafosfan solution in mice. Chin J Vet Sci Technol. 2005a;35: $574-8$.

Hasi S, Jiang J, Zhu B. Studies on Anti-heat stress effects and mechanisms of compound butafosfon solution. Acta Veterinaria Et Zootechnica Sinica. 2005b:36:1334.

Heo JH, Jung MH, Cho MH, Kim GH, Lee KC, Kim JH, Jung TS. The epidemiological study on fish diseases in the southern area of Kyeongnam. J Vet Clin. 2002;19:14-8.

Ji SC, Jeong GS, Im GS, Lee SW, Yoo JH, Takii K. Dietary medicinal herbs improve growth performance, fatty acid utilization, and stress recovery of Japanese flounder. Fish Sci. 2007;73:70-6. https://doi.org/10.1111/j.1444-2906.

Jollès $P$, Jollès J. What's new in lysozyme research? Mol Cell Biochem. 1984;63:165-89.

Kang DY, Kang HW, Kim GH, Jo HC, Kim HC. Effect of cold shock on the physiological responses of the cultured mullet, Mugil haematocheilus in witer. J Kor Fish. 2007:40:226-33.

Kim SS, Kim KW, Kim KD, Lee BJ, Han HS, Lee KJ. Optimum feeding rates for growing and sub-adult olive flounder Paralichthys olivaceus fed practical extruded pellets at high water temperature. Fisheries Aquatic Sci. 2015;48: 681-7. https://doi.org/10.5657/KFAS.2015.0681.

KOSIS. Investigation of fisheries aquaculture production 2018. Retrieved from http://kosis.kr/on May, 2019.

Kumari JY, Sahoo PK. Effects of cyclophosphamide on the immune system and disease resistance of Asian catfish, Clarias batrachus. Fish Shellfish Immunol. 2005;19:307-16. https://doi.org/10.1016/j.fsi.2005.01.008.

Lopes PA, Pinheiro T, Santos MC, Luz DA, Mathias M, Collares-Pereira MJ, ViegasCrespo AM. Response of antioxidant enzymes in freshwater fish populations (Leuciscus alburnoides complex) to inorganic pollutants exposure. Sci Total Environ. 2001;280:153-63. https://doi.org/10.1016/S0048-9697(01)00822-1.

Maule AG, Tripp RA, Kaattari SL, Schreck CB. Stress alters immune function and disease resistance in chinook salmon (Oncorhynuchus tshawytscha). Endochrinology. 1989;120:135-42. https://doi.org/10.1677/joe.0.1200135.

Mechesso AF, Kim YG, Park SC. Effects of butaphosphan and cyanocobalamin combination on plasma immune and biochemical parameters of olive flounder (Paralichthys olivaceus) subjected to crowding stress. Aquac Res. 2019;50:1611-7. https://doi.org/10.1111/are.14038.

MFDS. Ministry of Food and Drug Safety. Korea; 2013.

National Institute of Fisheries Sciences. Aquatic medicine catalogue. http://www. Nifs.go.kr/adms/index.ad (2018) Accessed 20 Jan 2010.

Palić D, Andreasen CB, Menzel BW, Roth JA. A rapid direct assay to measure degranulation of primary granules in neutrophils from kidney of fathead minnow (Pimephales promelas Rafinesque, 1820). Fish Shellfish Immunol. 2005;19:217-27. https://doi.org/10.1016/j.fsi.2004.12.003.

Pereira RA, Fensterseifer S, Barcelos VB, Martins CF, Schneider A, Schmitt E, Pfeifer LFM, Del Pino FAB, Correa MN. Metabolic parameters and dry matter intake of ewes treated with butaphosphan and cyanocobalamin in the early postpartum period. Small Rumin Res. 2013b;114:140-5. https://doi.org/10. 1016/j.smallrumres.2013.05.016.

Pereira RA, Siveira PAS, Montagner P, Schneider A, Schmitt E, Rabassa VR, Pfeifer LFM, Del Pino FAB, Pulga ME, Correa MN. Effect of butaphosphan and cyanocobalmin on postpartum metabolism and milk production in dairy cows. Animal. 2013a;7:1143-7. https://doi.org/10.1017/s1751731113000013.

Picchietti S, Mazzini M, Taddei AR, Renna R, Fausto AM, Mulero V, Abelli L. Effects of administration of probiotic strains on GALT of larval gilthead seabream: immunohistochemical and ultrastructural studies. Fish. Shellfish. Immunol. 2007;22:57-67.

Pickering AD. Stress the suppression of somatic growth in teleost fish. Prog Clin Biol Res. 1990;342:473.

Seo JS, Lee JH, Park JJ, Choi JS, Bae J, Lee CW, Yang CY, Kang YJ, Choi SH, Park $\mathrm{KH}$. Biochemical and stress-attenuationg effects of butaphosphancyanocobalamin combination drug in olive flounder Paralichthys olivaceus. Chem Biochem. 2020:1-10. https://doi.org/10.1007/s12562-019-01389-x.

Siwicki AK, Anderson DP. Nonspecific defense mechanisms assay in fish: II. Potential killing activity of neutrophils and macrophages, lysozyme activity in serum and organs and total immunoglobulin level in serum. In: Disease Diagnosis and Prevention Methods, Olsztyn, Poland; 1993. p. 105-12. https:// doi.org/10.1016/0165-2427(94)05430-Z. 
Sunyer JO, Tort L. Natural haemolytic and bactericidal activities of sea bream Sparus aurata serum are affected by the alternative complement pathway. Vet Immunol Immunopathol. 1995;45:333-45.

Tabeleao VC, Schwegler E, Pereira RA, Krause ART, Montagner P, Fejjo JO, Schneider A, Schmitt E, Brauner CC, Rabassa VR, Del Pino FAB, Correa MN. Combined butaphosphan and cyanocobalamin on the glucose metabolism of dairy cows after calving. Arq Bras Med Vet Zootec. 2017;69:317-24. https:// doi.org/10.1590/1678-4162-8453.

Wer RA, Peleteiro JB, Garcia Martin LO, Aldegunde M. The efficacy of 2phenoxyethanol, metomidate, clove oil and MS-222 as anesthetic agents in the Senegalese sole (Solea senegalensis Kaup 1858.). Aquaculture. 2009;288: 147-50. https://doi.org/10.1016/j.aquaculture.2008.11.024.

Yang SJ, Lee JY, Shin YK, Hwang HK, Myeong Jl. Effects temperature and salinity on survival, metabolism and histological change of the rockfish, Sebastes schlegeli. J Kor Soc Fish. 2016:28:1068-75. https://doi.org/10.13000/JFMSE. 2016.28.4.1068.

Yeh SP, Chang CA, Chan CY, Liu CH, Chen W. Dietary sodium alginate administration affects fingerling growth and juvenile non-specific immune responses of the orange-spotted grouper. Fish Shellfish Immunol. 2008;25: 19-27. https://doi.org/10.1016/j.fsi.2007.11.011.

Yuan C, Chen W, Sun F, Wu G, Gong Y, Han X. Administration of a herbal immunoregulation mixture enhances some immune parameters in carp Cyprinus carpio. Fish Physiol Biochem. 2007;33:93-101.

\section{Publisher's Note}

Springer Nature remains neutral with regard to jurisdictional claims in published maps and institutional affiliations.

Ready to submit your research? Choose BMC and benefit from:

- fast, convenient online submission

- thorough peer review by experienced researchers in your field

- rapid publication on acceptance

- support for research data, including large and complex data types

- gold Open Access which fosters wider collaboration and increased citations

- maximum visibility for your research: over $100 \mathrm{M}$ website views per year

At $\mathrm{BMC}$, research is always in progress.

Learn more biomedcentral.com/submissions 